\title{
BRICKS AND BOMBAST: U.S. PRESIDENTIAL ECONOMIC CHEERLEADING IN RESPONSE TO THE HOUSING MARKET
}

\section{Christopher Olds}

Fort Hays State University and the University of Texas, Rio Grande Valley, United States

E-mail: chris@chrisolds.com

\begin{abstract}
There is a long-standing discussion in the academic literature on whether presidential rhetoric mirrors or guides conditions in the sociopolitical environment. Scholars like Canes-Wrone (2001) and Edwards (2009) believe responsive presidential rhetoric that reflects what is happening in the sociopolitical environment is more likely to resonate with the public. This paper assesses whether presidents will heighten the usage of cheerleading rhetoric about the economy that uses a positive tone in response to changes in the housing market. The time series analyses of information available between 1963 to 2005 indicate presidents increase economic cheerleading in response to positive changes in the housing market.
\end{abstract}

Key-words: American presidency, rhetoric, political communication, housing market, interdisciplinary, macroeconomics, American politics

\section{Introduction}

Presidents and Vice Presidents of the United States are the only political officials voted on by all eligible voters in the country, a fact which compels presidential administations to believe they have the unique position of being the primary leader and representative of the country (Patterson 1990). When presidents make public remarks, one can view them as comments whereby the president acts as the chief spokesperson of the country (Cohen and Nice 2003). Given the unique bully pulpit presidents have as the symbolic leader of the country, this has led scholars to question whether presidents have the capacity to persuade others through their statements (Neustadt 1990).

It appears though that presidents will often struggle with changing the perspective of others through rhetoric when the point of view expressed by the president is fundamentally different from the perspective held by others (Hill 1998; Wood 2009). Given this, there is the belief that presidents must strategically use the reality of conditions to advance their policy agenda (Canes-Wrone 2001; Edwards 2009). The question then becomes the 
following: will presidential rhetoric reflect economic conditions to generate credibility with the public? The intention then is to examine whether presidential responsiveness to changes in the housing market lends support to the point of view that presidents are responsive leaders instead of direct leaders that speak about issues in a way that they personally prefer, like many politicians are apt to do (Fenno 1973; Wood 2009).

\section{Research Background and Empirically Testable Predictions}

\subsection{Presidents and the Economy}

Economic conditions are a fundamental part of how the public forms political evaluations (Campbell et al.,1960). The state of the economy is the core policy area used by the public to gauge performance of the president (EshbaughSoha and Peake 2011), regardless of how much influence the president even has over the state of the economy. Indeed, the very electoral prospects of a president and the president's party could be predicated on public perceptions of economic performance (Erickson 1989).

Wood (2007) proposes that presidents behave strategically and will talk about the economy in a way that improves the electoral chances of the president and their party. He surmises that presidents will speak optimistically about the economy in efforts to improve public approval ratings and heighten support. The empirical analyses of Wood (2007) do find that an increase in optimistic rhetoric about the economy results in shortlived increases in real personal expenditures on durable goods. This is evidence that cheerleading about economic conditions can shape public perceptions and behavior about the economy. Nonetheless, the question is whether there are limits to this relationship, as presidents can run the risk of losing their credibility if they speak in overly positive tones about the economy when conditions suggest otherwise.

The point here is that there will be instances when the president must acknowledge and reinforce the concerns of the public on aspects pertaining to the economy, otherwise they can be accused of being tone deaf and out of touch with the reality of the sociopolitical environment. Speaking about the economy in ways that match actual conditions helps the president be perceived as an authentic figure, which has the potential to make the public more receptive and responsive to the president's policy appeals. As CanesWrone (2001) suggests, the public is going to be more supportive of the president when the president talks about things in a manner the public already agrees with. Reinforcing the viewpoint of the public validates how 
the public thinks, which will make them more likely to listen to what the president has to say into the future. If presidents repeatedly try to tell the public what to think about the economy using a tone that does not match with contextual conditions at all, the public will tune the president out.

That is why presidents appear to tread carefully when deciding what tone to adopt when characterizing the economy given shifts in indicators seen as vital barometers of the overall health of the economy. The viability of the housing market is used as an indicator of whether the economy is in a growth or decline period (Case and Shiller 2003). A study of the market value of all residential assets in various countries illustrates a linkage between housing wealth and consumption values (Case, Quigley, and Shiller 2005). Vibrant housing markets are viewed as a sign of healthy economies, while dour housing markets are deemed a sign of weak economies. If a president repeatedly employs optimism in public remarks about the economy when the housing market is weak, they are potentially driving away the public with messaging that is incongruent with reality.

\subsection{Research Hypotheses}

Presidents are going to be responsive leaders in the face of prominent economic indicators like housing market conditions. When the housing market is doing well, the president will increasingly use optimistic language; this will be language that reflects actual conditions. When the housing market is doing poorly, presidential rhetoric will be less optimistic. The president's rhetoric on conditions pertaining to the housing market will match the tenor of the times. As a result, the following empirically testable research hypotheses are evaluated here:

Research Hypothesis \#1 - A prior increase in the number of housing units where construction has started significantly predicts an increase in presidential optimism about various aspects pertaining to the economy.

Research Hypothesis \#2 - A prior increase in the number of new housing units sold significantly predicts an increase in presidential optimism about various aspects pertaining to the economy.

These two hypotheses predict that signs of a healthy housing market (more construction on new homes and more homes sold) results in the United States president using cheerleading rhetoric about the economy. To see whether 
there is merit to any of these predictions, a dataset must be built that can test these hypotheses statistically.

\section{Dataset}

For the measurement of presidential rhetoric about aspects pertaining to the economy, a time series (variable measured across time) indicator using Wood's (2007) collected information on economic tone is used. Wood (2007) extracted sentences from the Public Papers of the Presidents based on a keyword search with the computer programming language Perl. The Public Papers of the Presidents contains all public remarks and statements made by presidents in the modern era.

To gauge the tone from the president about the general dimension of the overall economy, every sentence in the Public Papers that uses the phrase 'the economy' and/or 'our economy' is analyzed by human coders. If a sentence uses words that suggests a positive tone about the general economy, it is considered an optimistic statement. If a sentence uses words that suggest a negative tone about the general economy, it is considered a pessimistic statement. The number of negative sentences each month is subtracted from the number of positive sentences each month to gauge the general tone about the economy. This information on the general tone about the economy measured by itself (meaning not including information on tone that specifically mentions unemployment, inflation, and/or the deficit) was used in prior research by Olds (2013) and Olds (2015) to represent presidential rhetorical optimism on the economy.

To capture more specific elements of the economy though, Wood (2007) also extracts and uses human coders for the keyword 'unemployment' to measure tone on the matter of unemployment, the keyword 'inflation' to measure tone on inflation, and the keyword 'deficit' to measure the tone on the deficit. As was done with the general economy, the number of negative sentences each month for each specific keyword is subtracted from the number of positive sentences each month for each specific keyword. Adding up the sentences on these four dimensions provides a measure for presidential cheerleading rhetoric:

Presidential Cheerleading Rhetoric $=$ Monthly tone on general economy + Monthly tone on unemployment + Monthly tone on inflation + Monthly tone on the deficit 
The overall monthly sum of sentences along these four dimensions is the way in which optimism about the economy is measured. A graph of presidential cheerleading rhetoric on the economy for the period where data is available from Wood (2007) for the purposes of this study is provided below:

Figure 1: Monthly Time Series of Presidential Cheerleading Rhetoric

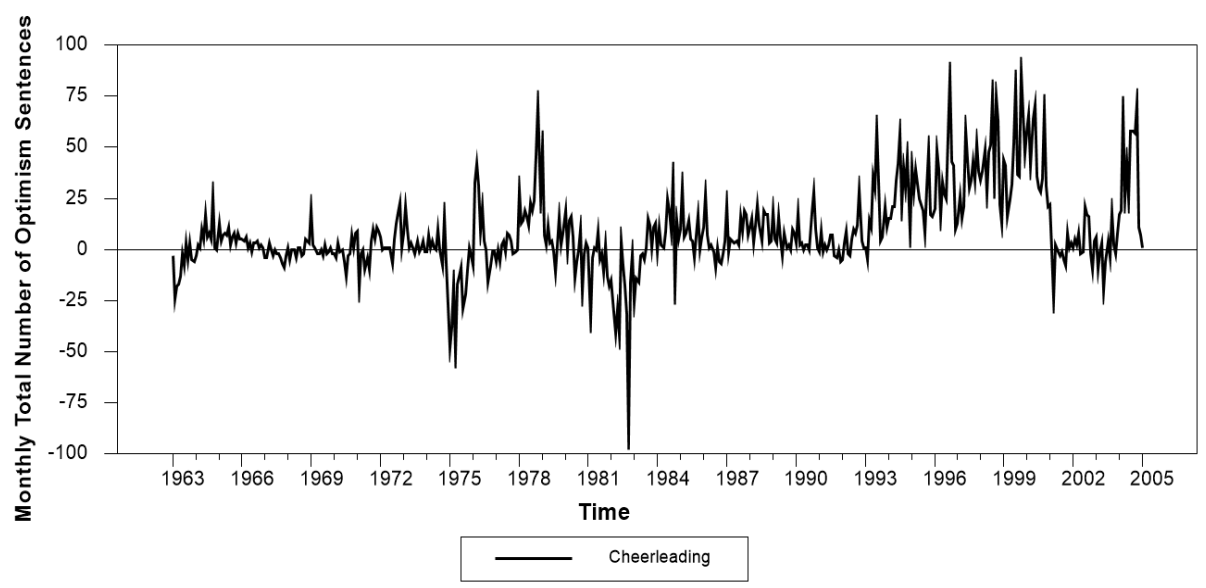

Source: Wood (2007)

Note that there are periods where the level of optimism is high above zero (suggesting a high level of optimism about the economy along the four dimensions) and periods where the level of optimism is well below zero (suggesting a high level of pessimism about the economy along the four dimensions). With this measure in place, it is necessary to have indicators of the housing market across time to see if changes in the housing market predict the level of presidential cheerleading about the economy.

Monthly totals on the number of housing starts comes from the United States Census Bureau (2018a). This measures the number of housing projects that begin in any given month, as represented by the total number of excavations started on the footings or foundation of a building. The total number of new houses sold during each month also comes from the United States Census Bureau (2018b) and tells us the number of new single-family homes sold based on information obtained by the Survey on Construction. Both time series are seasonally adjusted to account for seasonal patterns in home starts and new home sales, with the new home sales having a seasonally adjusted annual rate. With both measures of the housing market, it is possible 
to assess the influence of housing conditions on presidential economic cheerleading rhetoric. Since the information for the housing variables and presidential economic cheerleading rhetoric is available each month between January 1963 and January 2005, that is the time period in which the study will analyze. Although some might consider the lack of information on presidential economic tone since January 2005 to be a limitation, note that the review of monthly dynamics for forty-two years provides more than enough information for this initial empirical analysis on the relationship between the housing market and presidential economic tone.

It is important to mention that the potential relationship between the housing market and presidential economic cheerleading rhetoric can be influenced by endogenous variables and exogenous variables. Endogenous variables are factors whose values might depend on other variables being studied within the system of variables. For instance, presidential approval might influence presidential cheerleading rhetoric, and vice-versa. As a result, the percentage of the country in each month studied that approves of the job the president is doing is included. The information derives from Wood's (2007) collection of information from the Gallup organization, which asks a nationally representative sample of Americans if they approve or disapprove of the job the president is doing.

Another endogenous measure is the misery index, which is the sum of the unemployment rate and the inflation rate. A high misery index is an indicator of stagflation, whereby there is great difficulty in finding employment and there is reduced purchasing power on any income earned (Grabia 2011). The danger with a high misery index is that policy efforts to address unemployment can exacerbate inflation, while policy efforts to address inflation can ultimately lead to reduced employment levels. The misery index is calculated from information provided by the Bureau of Labor Statistics to the Data Planet (2018) repository. A change in the misery index has the potential to shift both presidential rhetoric and the housing market; it is certainly possible that shifts in the housing market or rhetorical style can bring about shifts in the misery index as well. Accounting for these possibilities makes it necessary to include the monthly calculated sum of the unemployment and inflation rates as calculated by the monthly Bureau of Labor Statistics reports.

Exogenous variables are those that are not potentially dependent on shifts to the aforementioned variables, yet they do have the potential to alter values observed in these aforementioned variables. One can think of exogenous variables in a time series analysis of this nature as akin to control variables to clarify the extent of the relationship between the endogenous variables. There 
are dichotomous dummy variable indicators (coded as a 0 for not being in the time period and 1 for being in the time period) accounting for recession periods, the start of military conflicts as identified by the Congressional Research Service (e.g. the first and second Iraq campaigns), the September $11^{\text {th }}$ terrorist attacks, the passage of major economic initiatives proposed and promoted by the president, the month of presidential elections and congressisonal midterm elections, and unique presidential administrations (Kennedy, Johnson, Nixon, Ford, Carter, H.W. Bush, and Clinton). A dummy indicator for George W. Bush is not included, as this administration can be considered the reference level statistically; one presidential administration indicator must be left out of the model to avoid any estimation issues. All replication materials for this project are available at https://dataverse.harvard.edu/dataverse/christopherolds.

\section{Research Methodology}

The time series approach used to assess causal direction is vector autoregression, while the magnitude and polarity of relationships are evaluated with moving average representation. Vector autogression allows for each designated endogenous variable to be predicted by prior values of itself, as well as prior values of all the other endogenous variables. Put more simply, the goal is to see if past values of variables predict current values of variables. Including multiple lags (prior values) of each endogenous variable also accounts for the inertial qualities of variables, which means past values of one variable are going to heavily influence the values that follow for that same variable (Sims 1980).

In vector autoregession, Granger causality tests are performed to see if the prior values of a variable can predict the values of another variable in the endogenous variable system. With each hypothesis in this project, there are four endogenous variables in the system (misery index, presidential approval, presidential economic cheerleading rhetoric, and a housing market indicator). Any criticism that variables are left unaccounted for in the system should consider both that there are exogenous controls included, and that any variables omitted from the system are accounted for by prior values of the endogenous variables in the vector autoregression model (Eshbaugh-Soha and Peake 2011, 135).

For each of the two vector autoregression models analyzed, a series of Engle-Granger tests are performed at different lag lengths to see if the endogenous variables are cointegrated. Cointegrated variables share a common trend across time, and standard vector autoregression techniques 
should not be performed if there is any inkling of cointegrated variables. The Engle-Granger test results presented in Table 1 indicate that neither vector autogression system has cointegrated variables, as the unit root tests on regression residuals in the two systems suggest the null hypothesis of no cointegration should not be rejected.

Vector autoregression is a helpful means to learn more about the potential causal relationship between variables but is not particularly useful in terms of assessing the polarity or magnitude of the relationship between variables. Because of the presence of so many lags in the vector autogression, any coefficient estimates are plagued by multicollinearity concerns. This makes moving average representation procedures necessary.

Table 1: Engle-Granger Cointegration Diagnostic Test Results

\begin{tabular}{|c|c|c|c|c|c|}
\hline Model & $\begin{array}{c}\text { Engle- } \\
\text { Granger } \\
\text { Test A }\end{array}$ & $\begin{array}{c}\text { Engle- } \\
\text { Granger } \\
\text { Test B }\end{array}$ & $\begin{array}{c}\text { Engle- } \\
\text { Granger } \\
\text { Test C }\end{array}$ & $\begin{array}{c}\text { Engle- } \\
\text { Granger } \\
\text { Test D }\end{array}$ & $\begin{array}{c}\text { Engle- } \\
\text { Granger } \\
\text { Test E }\end{array}$ \\
\hline $\begin{array}{c}\text { Hypothesis } \\
\# 1 \\
\text { Housing } \\
\text { Units } \\
\text { Started } \\
\text { Model }\end{array}$ & $\begin{array}{c}\text { \# of lags: } 5 \\
\text { test statistic: } \\
-2.77249 \\
\text { critical value } \\
.01:-4.68391 \\
\text { critical value } \\
.05:-4.12158 \\
\text { critical value } \\
.10:-3.82765\end{array}$ & $\begin{array}{c}\text { \# of lags: } 6 \\
\text { test statistic: } \\
-2.76547 \\
\text { critical value } \\
.01:-4.68398 \\
\text { critical value } \\
.05:-4.12162 \\
\text { critical value } \\
.10:-3.82769\end{array}$ & $\begin{array}{c}\text { \# of lags: } 7 \\
\text { test statistic: } \\
-2.66696 \\
\text { critical value } \\
.01:-4.68405 \\
\text { critical value } \\
.05:-4.12166 \\
\text { critical value } \\
.10:-3.82772\end{array}$ & $\begin{array}{c}\text { \# of lags: } 8 \\
\text { test statistic: } \\
-2.71127 \\
\text { critical value } \\
.01:-4.68412 \\
\text { critical value } \\
.05:-4.12171 \\
\text { critical value } \\
.10:-3.82776\end{array}$ & $\begin{array}{c}\text { \# of lags: } 9 \\
\text { test statistic: } \\
-2.54841 \\
\text { critical value } \\
.01:-4.68419 \\
\text { critical value } \\
.05:-4.12175 \\
\text { critical value } \\
.10:-3.82779\end{array}$ \\
\hline $\begin{array}{c}\text { Hypothesis } \\
\# 2 \\
\text { Housing } \\
\text { Units Sold } \\
\text { Model }\end{array}$ & $\begin{array}{c}\text { \# of lags: } 1 \\
\text { test statistic: } \\
-3.45775 \\
\text { critical value } \\
.01:-4.68364 \\
\text { critical value } \\
.05:-4.12140 \\
\text { critical value } \\
.10:-3.82752\end{array}$ & $\begin{array}{c}\text { \# of lags: } 2 \\
\text { test statistic: } \\
-3.16364 \\
\text { critical value } \\
.01:-4.68370 \\
\text { critical value } \\
.05:-4.12145 \\
\text { critical value } \\
.10:-3.82756\end{array}$ & $\begin{array}{c}\text { \# of lags: } 3 \\
\text { test statistic: } \\
-2.86077 \\
\text { critical value } \\
.01:-4.68377 \\
\text { critical value } \\
.05:-4.12149 \\
\text { critical value } \\
.10:-3.82759\end{array}$ & $\begin{array}{c}\text { \# of lags: } 4 \\
\text { test statistic: } \\
-2.81743 \\
\text { critical value } \\
.01:-4.68384 \\
\text { critical value } \\
.05:-4.12153 \\
\text { critical value } \\
.10:-3.82762\end{array}$ & $\begin{array}{c}\text { \# of lags: } 5 \\
\text { test statistic: } \\
-2.75976 \\
\text { critical value } \\
.01:-4.68391 \\
\text { critical value } \\
.05:-4.12158 \\
\text { critical value } \\
.10:-3.82765\end{array}$ \\
\hline
\end{tabular}

Source: Original data analysis using WinRats Standard

Note: The null hypothesis is no cointegration present

With moving average representation, a simulated shock (change) is imposed on a single variable in the endogenous system. The purpose is to see how other variables react across time when there is an increase to a specific variable. When a specific variable shifts upward, do other variables increase or decrease in magnitude, and for how long does this increase or decrease 
last? Moving average representation provides the answer. After a shock to a single variable, how other variables respond is made clear. In order to make sure there is a uniform interpretation regarding the size of change in variables when there is a shock introduced into the system, all the endogenous variables are standardized. That means the endogenous variables are rescaled to have a mean of 1 and a standard deviation of 0 . Placing the endogenous variables on a common metric like this makes it easier to interpret how much of an effect changing a specific variable has on other variables in the system.

\section{Research Results}

The results of the analyses provide clear support for both Hypothesis \#1 and Hypothesis \#2, suggesting that for the time period studied, presidential administrations are strategically responsive to the housing market in the tone of their rhetoric about the economy. Prior values about housing conditions do predict current values of presidential cheerleading about the economy, and a positive increase in housing market indicators results in an increase in presidential cheerleading about the economy.

In terms of Hypothesis $\# 1$, it is important to note from the vector autoregression results reported in Table 2 on the next page that the only two variables in the endogenous system that predict presidential cheerleading rhetoric about the economy are prior values in new housing units started ( $p$ value $=.03$ ) and prior levels of presidential economic cheerleading ( $\mathrm{p}$-value = .00). Presidential economic cheerleading rhetoric does not appear to be responsive to prior values of the misery index ( $p$-value $=.65$ ) or prior values in presidential approval ( $\mathrm{p}$-value $=.71$ ).

Changes in the number of housing units started seems to influence the usage of presidential economic cheerleading rhetoric; this serves as evidence that presidents employ responsive leadership about the economy with changes in specific indicators. Housing units started is something that members of the public see. It is a tangible measure of the state of the economy, whereas the misery index is not something that is clearly seen and is more of an abstract concept about the economy. Housing being constructed is observable with people's own eyes, while the misery index is not necessarily information that is immediately observable and processed by the public. This comment is reinforced by the findings that prior housing units started predicts presidential approval ( $p$-value $=.01$ ) and prior values of the misery index do not predict approval ratings ( $p$-value $=.23$ ). So, if presidents were to alter their cheerleading rhetoric in ways that are not responsive to housing 
units being sold, all presidents risk being perceived by the public as not credible. The vector autoregression results indicate presidents will respond to the recent levels in new housing units started.

Table 2: Vector Autogression Granger Tests Results for Hypothesis \#1

\begin{tabular}{|l|c|c|}
\hline \multicolumn{1}{|c|}{ Independent Variable } & Dependent Variable & \multicolumn{1}{c|}{$\begin{array}{c}\text { p-value } \\
\text { (F-statistic) }\end{array}$} \\
\hline Misery Index $\rightarrow$ & Misery Index & $.00(357.0578)$ \\
\hline Presidential Approval $\rightarrow$ & & $.00(3.2188)$ \\
\hline New Housing Units Started $\rightarrow$ & & $.00(3.2894)$ \\
\hline Presidential Cheerleading & & $.51(0.9114)$ \\
\hline Misery Index & $\begin{array}{c}\text { Presidential } \\
\text { Approval }\end{array}$ & $.23(1.3237)$ \\
\hline Presidential Approval $\rightarrow$ & & $.00(251.8371)$ \\
\hline New Housing Units Started $\rightarrow$ & & $.01(2.5116)$ \\
\hline Presidential Cheerleading & & $.19(1.4037)$ \\
\hline & & $.01(2.7764)$ \\
\hline Misery Index $\rightarrow$ & New Housing Units & $.89(0.4550)$ \\
\hline Presidential Approval & Started & $.00(131.2485)$ \\
\hline New Housing Units Started $\rightarrow$ & & $.57(0.8387)$ \\
\hline Presidential Cheerleading & & $.65(0.7518)$ \\
\hline & & $.71(0.6791)$ \\
\hline Misery Index & Presidential \\
\hline Presidential Approval & & $.03(2.1219)$ \\
\hline New Housing Units Started $\rightarrow$ & & $.00(11.4611)$ \\
\hline Presidential Cheerleading $\rightarrow$ & & \\
\hline
\end{tabular}

Source: Original data analysis using WinRats Standard

Note: Arrows in table represent Granger-causality from the block of coefficients for the independent variable to the dependent variable using a .10 level of significance. The p-value results are from F-tests for a null hypothesis of no Granger-causality. The system includes a deterministic constant, as well as exogenous control indicators for recessions, the start of military conflicts in Lebanon, Grenada, Iraq in 1990, Iraq in 2003, the September $11^{\text {th }}$ terrorist attacks, presidential and congressional midterm elections, and unique presidential administrations. For the sake of space and clarity, the results for the exogenous controls are not included here. Each of the independent variables in the endogenous system include eight monthly lags to control for the inertia of variables. Lag length is selected by Akaike Information Criterion. 
It is also important to note here that prior values in presidential cheerleading do not significantly predict current values in new housing units started (p-value $=.57$ ). The construction of new houses for the time period studied does not appear to be influenced by the level of presidential cheerleading about the economy. Instead, prior values of the misery index ( $p$ value $=.01)$ and prior values of new housing units started $(\mathrm{p}$-value $=.00)$ significantly predict the current value of new housing units started. It makes sense that changes in the misery index will influence the construction of new housing; the combined level of unemployment and inflation will determine whether there are potential buyers for homes and determines the price of materials/resources necessary in starting a new home.

With respect to the magnitude and the polarity of the relationship between variables, the impulse responses of the moving average representation for Hypothesis \#1 support the prediction that an increase in new housing construction results in an increase in presidential economic cheerleading rhetoric. Figure 2 provides the responses of variables in the endogenous system to simulated shocks for each of the four variables in the system. The 95\% confidence intervals, represented by the dashed lines in each plot, are determined by Monte Carle integration and the fractile method (Sims and Zha 1999). The number of months following a positive shock to a variable is represented by the horizontal axis of each plot. The extent of positive or negative movement away from the standardized mean is represented by the vertical axis of each plot. The variable that is given a positive one standard deviation increase change (shock) is the same within each unique column in Figure 2 on the next page.

This means the plots along the first column represent the response variables have to a positive shock in the misery index, the plots along the second column represent the response variables have to a positive shock in presidential approval, the plots along the third column represent the response variables have to a positive shock in new housing units started, and the plots along the fourth column represent the response variables have to a positive shock in presidential economic cheerleading.

For the purposes of Hypothesis \#1, it is essential that we look at column three, row four. This specific plot shows the response of presidential economic cheerleading rhetoric following a one standard deviation increase in new housing units started. Although it looks like the level of presidential economic cheerleading rhetoric does not significantly move away from the standardized mean of zero at first, presidential economic cheerleading rhetoric is clearly bounded away from zero six months after the shock. This indicates that it takes awhile before presidential rhetoric is clearly responsive 
to new housing construction, but the level of cheerleading increases (is more positive in tone) six months after an increase in new housing units started has passed. There is a .10 standard deviation increase in the level of presidential economic cheerleading rhetoric.

Figure 2: Moving Average Representation Responses for Hypothesis \#1

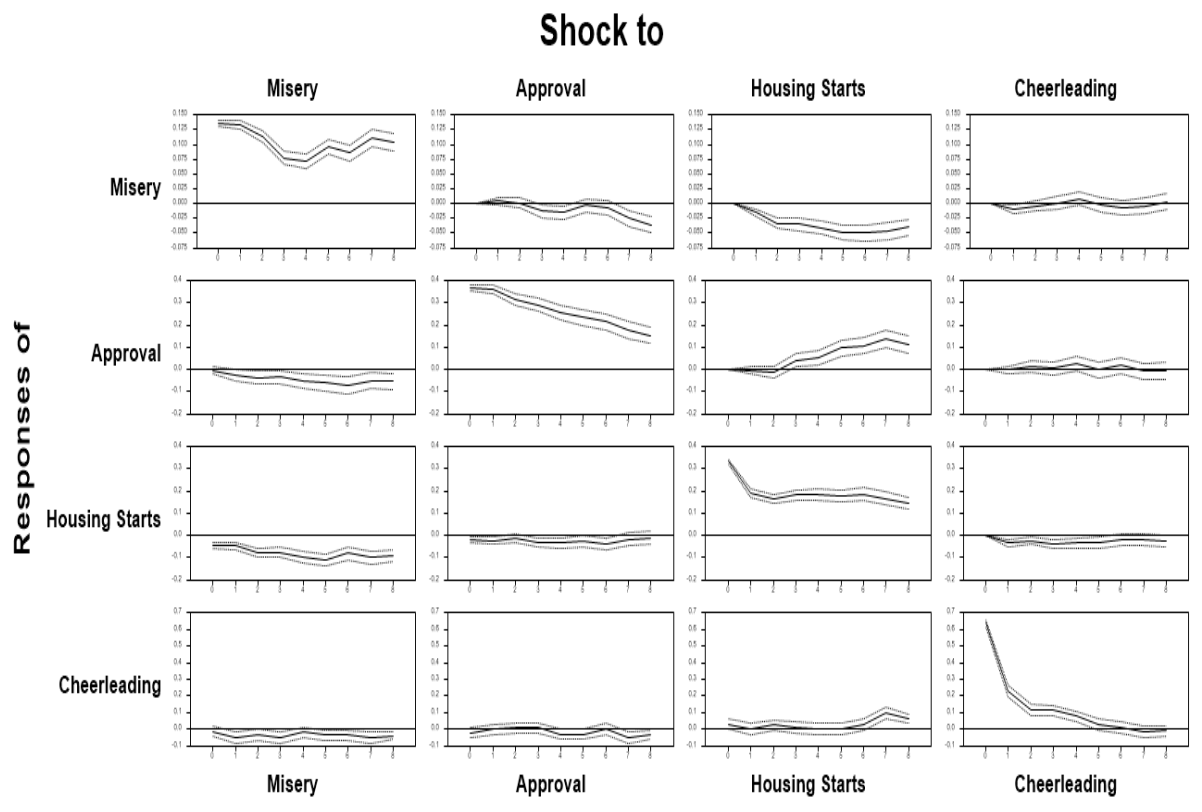

Source: Original data analysis using WinRats Standard

Note: Dashed lines represent the 95\% confidence interval, while the solid line inside the confidence interval represents the estimated standard deviation change in a variable.

The results of the vector autoregression for Hypothesis \#2 tell a similar tale as the results observed for the analysis of the endogenous system for Hypothesis \#1. The results of the second vector autoregression are reported in Table 3 on the next page. Once again, prior change in the housing market predicts current levels of presidential economic cheerleading rhetoric. The number of new housing units sold Granger-causes presidential economic cheerleading ( $p$-value $=.00)$, and prior values of presidential economic cheerleading predicts current values of itself, suggesting the variable is inertial ( $\mathrm{p}$-value $=.00)$. The president is again exhibiting responsive leadership by reacting to housing market conditions. The level of housing sold 
predicts the tone the president adopts when discussing various aspects pertaining to the economy.

Table 3: Vector Autogression Granger Tests Results for Hypothesis \#2

\begin{tabular}{|l|c|c|}
\hline \multicolumn{1}{|c|}{ Independent Variable } & Dependent Variable & $\begin{array}{c}\text { p-value } \\
\text { (F-statistic) }\end{array}$ \\
\hline Misery Index $\rightarrow$ & Misery Index & $.00(1331.60)$ \\
\hline Presidential Approval $\rightarrow$ & & $.01(4.5617)$ \\
\hline New Housing Units Sold $\rightarrow$ & & $.08(2.5886)$ \\
\hline Presidential Cheerleading & & $.33(1.0988)$ \\
\hline Misery Index & $\begin{array}{c}\text { Presidential } \\
\text { Approval }\end{array}$ & $.19(1.6584)$ \\
\hline Presidential Approval $\rightarrow$ & & $.00(1035.14)$ \\
\hline New Housing Units Sold & & $.72(0.3320)$ \\
\hline Presidential Cheerleading & & $.88(0.1330)$ \\
\hline & & $.01(4.7805)$ \\
\hline Misery Index $\rightarrow$ & New Housing Units & Sold \\
\hline Presidential Approval & & $.82(0.1993)$ \\
\hline New Housing Units Sold $\rightarrow$ & & $.00(511.4461)$ \\
\hline Presidential Cheerleading & & $.41(0.8826)$ \\
\hline & & $.31(1.1685)$ \\
\hline Misery Index & $\begin{array}{c}\text { Presidential } \\
\text { Cheerleading }\end{array}$ & \\
\hline Presidential Approval & & $.00(6.0031)$ \\
\hline New Housing Units Sold $\rightarrow$ & & $.00(49.5154)$ \\
\hline Presidential Cheerleading $\rightarrow$ & & \\
\hline
\end{tabular}

Source: Original data analysis using WinRats Standard

Note: Arrows in table represent Granger-causality from the block of coefficients for the independent variable to the dependent variable using a .10 level of significance. The p-value results are from F-tests for a null hypothesis of no Granger-causality. The system includes a deterministic constant, as well as exogenous control indicators for recessions, the start of military conflicts in Lebanon, Grenada, Iraq in 1990, Iraq in 2003, the September $11^{\text {th }}$ terrorist attacks, presidential and congressional midterm elections, and unique presidential administrations. For the sake of space and clarity, the results for the exogenous controls are not included here. Each of the independent variables in the endogenous system include two monthly lags to control for the inertia of variables. Lag length is selected by Akaike Information Criterion.

Note again that presidential economic cheerleading rhetoric does not Granger-cause the level of new housing units sold ( $\mathrm{p}$-value $=.41)$. Instead, the 
level of housing units sold is significantly influenced by prior values of the misery index ( $p$-value $=.01$ ) and prior values of itself, suggesting the variable also has inertial qualities ( $\mathrm{p}$-value $=.00$ ). The housing market conditions are not responding to recent changes in presidential rhetoric but are responsive to recent changes in the combined level of unemployment and inflation. It is logical that recent employment levels and prices will shape the current level of housing units that are sold.

One aspect of difference from Hypothesis \#1 is that the housing market indicator does not predict presidential approval ratings. Prior values of new housing units sold does not Granger-cause current presidential approval ( $p$ value $=.72$ ). It could be that the number of housing units sold is something that the public does not clearly see with their own eyes in the way that new housing construction is easily visible.

Figure 3: Moving Average Representation Responses for Hypothesis \#2

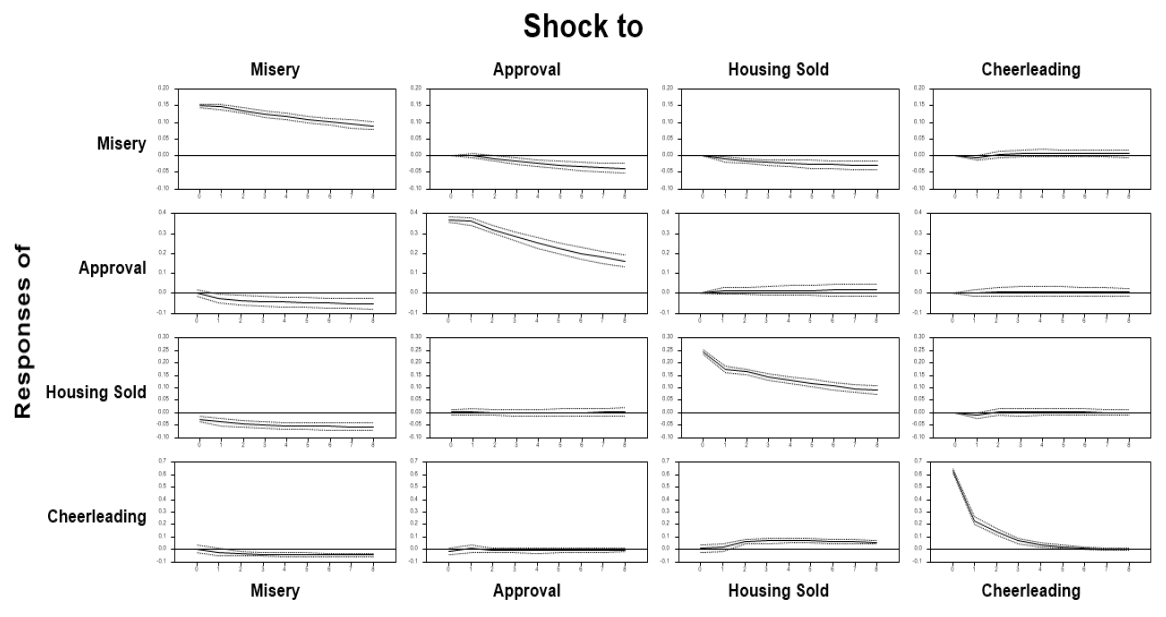

Source: Original data analysis using WinRats Standard

Note: Dashed lines represent the $95 \%$ confidence interval, while the solid line inside the confidence interval represents the estimated standard deviation change in a variable.

The moving average representation analysis for Hypothesis \#2 offers clear support for the prediction that an increase in new housing units sold increases presidential economic cheerleading. The plot in column three and row four in Figure 3 above shows the response of presidential rhetoric to a one standard deviation increase in the number of new housing units sold. By month two following the positive increase in new housing units sold, 
presidential economic cheerleading rhetoric is clearly bounded away from the standardized mean of zero. At month two, there is a 10 standard deviation increase in the level of presidential economic cheerleading rhetoric that persists for several months afterward. Such a result means there is a positive relationship between new housing units sold and presidential economic cheerleading rhetoric. The president's tone about the economy is more positive when the number of new housing units sold increases.

\section{Conclusion}

The interest of this project was to see whether there is any credence to a proposal derived from Canes-Wrone (2001) and Edwards (2009) that responsive presidential rhetoric reflecting what has been happening in the sociopolitical environment is observable with empirically testable information contrasting economic tone and housing conditions. The results of the analyses indicate that presidents are responsive leaders, employing a more positive tone in economic rhetoric about the general state of the economy, the level of unemployment, the level of inflation, and the level of the deficit when indicators of the housing market improve. An increase in new housing units being constructed is a cue to the president that there is a willingness to take risk in the economic marketplace by going through the cost-intensive process of building new housing. More housing units being constructed tells presidents it is appropriate to speak about the economy in positive terms. The same goes for new housing units sold. If there is an increase in new housing purchased, that is a sign that there is a willingness to take risk in the economic marketplace by going through the process of acquiring property. More houses being sold tells the president that it would be credible to amplify the level of cheerleading rhetoric about the economy.

This project is by no means the definitive account on the matter of presidential rhetorical responsiveness to the housing market. For starters, while the paper focused on two very important indicators of the housing market, there are other indicators that future scholars should study, such as the national foreclosure rate and house price index by region of the country.

An additional consideration is that this analysis uses information about tone in the economy provided by Wood (2007), which has a dataset that ends in January 2005. While the level of resources needed are significant, scholars are encouraged to employ human coders to measure extracted sentences from the Public Papers of the Presidents to have information coded up to the present day. It will be very useful to learn about whether the results observed in this current analysis hold when accounting for a time period that includes 
the Great Recession, President Obama's economic stimulus policies, and President Trump's consistently braggadocious approach to discussing the economy.

Another path includes the collection and analysis of housing indicator and elite rhetoric information from other countries. This can help us see whether the results observed in the U.S. are present in other contexts. Hopefully this project is merely an initial step and a conversation starter in the academic literature on the connection between housing conditions and presidential economic cheerleading rhetoric.

\section{References}

Campbell, Angus, Philip E. Converse, Warren E. Miller, and Donald E. Stokes. 1960. The American voter. Wiley.

Canes-Wrone, Brandice. 2001. "The president's legislative influence from public appeals." American Journal of Political Science 45 (2): 313-329.

Case, Karl E., John M. Quigley, and Robert J. Shiller. 2005. "Comparing wealth effects: the stock market versus the housing market." Advances in Macroeconomics 5 (1):1-32.

Case, Karl E., and Robert J. Shiller. 2003. "Is there a bubble in the housing market?" Brookings Papers on Economic Activity 2: 299-342.

Cohen, Jeffrey, and David Nice. 2003. The presidency. McGraw-Hill Humanities, Social Sciences \& World Languages.

Data-Planet. Misery Index: Misery Index, 01/1948 - 05/2018. 2018. Data Planet $^{\mathrm{TM}}$ Statistical Datasets: A SAGE Publishing Resource [Dataset]. (201806-05). Dataset-ID: 077-003-001.

Edwards III, George C. 2009. The strategic president: Persuasion and opportunity in presidential leadership. Princeton University Press.

Erikson, Robert S. 1989. "Economic conditions and the presidential vote." American Political Science Review 83 (2): 567-573. 
Eshbaugh-Soha, Matthew, and Jeffrey S. Peake. 2011. Breaking through the noise: Presidential leadership, public opinion, and the news media. Stanford University Press.

Fenno Jr, Richard F. 1973. Congressmen in committees. Little Brown \& Company.

Grabia, Tomasz. 2011. "The Okun misery index in the European Union countries from 2000 to 2009." Comparative Economic Research 14 (4): 97115.

Hill, Kim Quaile. 1998. "The policy agendas of the president and the mass public: A research validation and extension." American Journal of Political Science 42 (4): 1328-1334.

Neustadt, Richard E. 1990. Presidential power and the modern presidents: The politics of leadership from Roosevelt to Reagan. The Free Press.

Olds, Christopher. 2013. "Contrasting the misery index, presidential rhetorical optimism on the economy, and public attitudes regarding government involvement in domestic affairs." The Empirical Economics Letters 12 (10): 1041-1050.

Olds, Christopher. 2015. "The negative effect of economic policy uncertainty on presidential rhetorical optimism about the economy in the United States." Economics, Management \& Financial Markets 10 (2): 54-76.

Patterson, Thomas E. 1990. The American democracy. McGraw-Hill.

Sims, Christopher A. 1980. "Macroeconomics and reality." Econometrica: Journal of the Econometric Society 48 (1): 1-48.

Sims, Christopher A., and Tao Zha. 1999. "Error bands for impulse responses." Econometrica 67 (5): 1113-1155.

United States Census Bureau. Housing Starts: Total Housing Starts Seasonally Adjusted, 01/1960 - 07/2018. 2018. Data Planet ${ }^{\mathrm{TM}}$ Statistical Datasets: A SAGE Publishing Resource [Dataset]. Dataset-ID: 001-034-001 
United States Census Bureau. New Homes Sold by Stage of Construction: Homes Sold at End of Period - Total | Category: Seasonal Adjusted, 01/1963 04/2018. 2018. Data Planet ${ }^{\mathrm{TM}}$ Statistical Datasets: A SAGE Publishing Resource [Dataset]. Dataset-ID: 001-016-001

Wood, B. Dan. 2007. The politics of economic leadership: The causes and consequences of presidential rhetoric. Princeton University Press.

Wood, B. Dan. 2009. The myth of presidential representation. Cambridge University Press. 